\title{
The Influence of Fire and Deforestation on the Floral Symmetry and Fitness of Adenocalymma nodosun (Bignoniaceae)
}

\author{
V StEFANI ${ }^{1}$, D LANGE ${ }^{2}$, AA VILELA ${ }^{1}$, CA FERRERIA $^{1}$, K DEL-CLARO $^{1}$ \\ 1 - Laboratório de Ecologia, Comportamento \& Interações, Universidade Federal de Uberlândia, Minas Gerais, Brazil \\ 2 - Universidade Tecnológica Federal do Paraná, Campus Santa Helena, Paraná, Brazil
}

\section{Article History \\ Edited by \\ Gilberto M. M. Santos, UEFS, Brazil \\ Received 12 December 2016 \\ Initial acceptance 13 February 2017 \\ Final acceptance 14 February 2017 \\ Publication date 17 October 2017}

\section{Keywords}

Cerrado, Pollinator-Plant, Analysis of the Soil.

\section{Corresponding author}

Vanessa Stefani

Laboratório de Ecologia

Comportamental e de Interações

Universidade Federal de Uberlândia

Av. Pará, 1720 - CEP 38400-902

Uberlândia-MG, Brasil.

E-mail: vastefani@hotmail.com

\begin{abstract}
Burnings and deforestation are severe disturbances to plants and may represent a stressful situation for plant growth, and they can also affect plant-pollinator interactions and the reproductive success of plants. In this study, we verified the variation in floral symmetry of Adenocalymma nodosum (Bignoniacea) in two areas, one post-fire and other after deforestation. We also verified the effects on plant-pollinator interactions and fruit set production. Results showed that $A$. nodosum flowers were more asymmetric in mowing areas than in fire areas. Asymmetrical flowers presented low nectar concentration and bee visitation rates. Although mowed environments produce fewer fruits and seeds than areas affected by fire, the change was not significant. Soil from the burnt area showed higher nutrient and organic matter concentration and less aluminum than that of mowed areas. Our results showed that $A$. nodosum flowers in the deforestation area are more asymmetric than those in the post-fire area. This result suggest that Cerrado plants may be less adapted to deforestation than to fire, since they have been facing fire events for thousand years in this biome. We suggest that the effects of environmental stress on the development and fitness of plants may provide an important breakthrough to the understanding of insect-plant interactions in Cerrado savanna, where burnings and deforestation are frequent anthropogenic effects.
\end{abstract}

\section{Introduction}

Burning and deforestation are disturbances that affect the most diverse ecological processes by dramatically influencing the structure, composition and nutrient cycling of terrestrial ecosystems (Coutinho, 1990; Smithwick et al., 2005). These disturbances are common in Neotropical savanna areas, and Brazilian savanna or Cerrado is the most diverse of them (Gottsberger \& Silberbauer-Gottsberger, 2008). The abundance of dead dry biomass, mainly from grass, results in bushfires (Bond \& Keely, 2005) able to alter the ecological relationships between animals and plants in this system during the cold season and drought (Del-Claro \& Marquis, 2015; Fagundes et al., 2015). Adjustments to the presence of the fire were imposed to the plants (Coutinho, 1990; Gottsberger \& Silberbauer-Gottsberger, 2008; Simon et al., 2009; Silva \& Batalha, 2010a, b) due to constant burns in the Cerrado that date back to times prior to the human occupation of the continent (Hoffmann \& Moreira, 2002; Miranda, 2002). In addition, the fire is a negative disturbance that causes structural and physiological stress and it alters the performance and development of plants (Schmidt et al., 2005). Deforestation has a significant effect on species and ecosystems. The death of species is inevitable in mowed natural areas and in areas replaced by urban or agricultural sites. It affects all the destructed environments and causes local erosion, climate changes and soil impoverishment (Hajabbasi et al., 1997; Christian et al., 2008). Thus, plants that sprout in a Cerrado area completely changed by deforestation may suffer significant effects on their development and survival (Rizzini, 1962; Hoffmann, 1998).

The analysis of symmetry was the tool used to check the impact of disturbances, whether of biotic or abiotic origin, on the development of plants. For example, the fluctuating 
asymmetry (FA) consists of verifying small random variations or the instability in the right and left sides of bilateral-character bodies, which deviate from perfect symmetry (Cornelissen \& Stiling, 2005; Graham et al., 2010). These instabilities in symmetry result from the genotype inability to produce the same Phenotype in a particular environment or under certain conditions (Møller \& Swaddle, 1997). It indicates an interference in the stability of character development due to genetic or environmental stress (Polak, 2003; Graham et al., 2010; Cuevas-Reyes et al., 2011). These disturbances affect not only the bilateral growth patterns of the body, but they can also negatively affect plant fitness (Díaz et al., 2004; Graham et al., 2010; Alves-Silva \& Del-Claro, 2015).

Plant-pollinator interactions select the flowers that will be visited and depend on the quality of the provided remedy (Møller \& Eriksson, 1994; Ferreira \& Torezan-Silingardi, 2013), this floral quality will directly affect the reproduction success of plants. Thus, the shape, size, color of the floral structure and the quality of reward most likely result from coevolution characters between plants and their pollinators (Møller, 1995; Torezan-Silingardi, 2011; Pellegrino, 2015). Accordingly, recent studies are seeking to understand the relationship between the intraspecific variation in the morphology of the flowers and their reflection on the fitness of the plant, whereas pollinating insects exhibit preferences for visiting symmetrical flowers (Milligan et al., 2008; Frey \& Bukoski, 2013; Daloso, 2014). Therefore, the symmetry may be indicative of a floral of good quality and it would affect the attractiveness and the pollinator visitation rates, as well as increase the reproductive potential of plants (Møller \& Eriksson, 1995; Frey \& Bukoski, 2013).

The overall aim of the present study is to verify whether the floral symmetry of a pioneer species typical of the Cerrado, Adenocalymma nodosum (Silva Manso) L.G. Lohmann (Bignoniaceae), is more affected by fire or by mowing. We formulated three questions to address such aim: (1) Are flowers produced by plants that sprouted after a deforestation process more asymmetric those flowers from burned areas? (2) Do these flowers have similar quality resources and are, consequently, attractive to pollinators? (3) Is there difference in the fruit and seed production of plants of these two areas? Our hypothesis is that flowers from both the burnt and the mowing areas will be asymmetric; however, the degree of variation in the symmetry will be smaller in the burnt area, because plants are less adapted to deforestation than to fire. Consequently, asymmetrical flowers will be less attractive to pollinators and; therefore, less visited; thus, they will negatively influence the fruit and seed production of these plants.

\section{Materials and Methods}

Study and sampling area

The study was conducted next to the Clube Caça e Pesca Itororó ecological reserve, $\left(18^{\circ} 58^{\prime} 00^{\prime \prime} \mathrm{S}\right.$ and $48^{\circ} 17^{\prime} 30^{\prime \prime}$
W - CCPIU), located in Uberlândia, Minas Gerais State, Brazil. The region is located in Cerrado biome with dirty field gradients and the presence of tree and shrub plants (from 10 to $60 \%$ coverage) in an area dominated by grasses (Eiten, 1972).

Adenocalymma nodosum is a caespitose shrub with flexible branches up to $2 \mathrm{~m}$ high (Tresvenzol et al., 2010). Its leaves are petiolate, bi or tripinnate and imparipinnate, its leaflets are narrow and lanceolate, sessile when simple, petiolate when they are compound leaflets and the flowers arise in the axils of bracts (Sampaio et al., 2016). The plant species studied is important for the reproductive pollinating insects (Sampaio et al., 2016).

Two groups of $A$. nodosum that have suffered different types of environmental degradation were used in the present study: a) post-fire area, re-growth group with 30 plants, located in a fire recovery area, distributed over approximately 2.1 hectares; b) post- deforestation area (four years without fire event), regrowth group with 30 plants, located in a recovery area, mechanical clearing close to the ground, spread over approximately 1.9 hectare.

Adenocalymma nodosum individuals were randomly selected in November 2013, one month after the areas were burnt or cleared. The study was conducted during the plant-breeding season, which occurred between January and April 2015. The subjects from the two populations were approximately $1.5 \mathrm{~m}$ tall and had the same phenological state, approximately the same number of branches, leaves and flower bud formations.

\section{Floral resources}

Fifteen flower buds were bagged with voile in the late afternoon in the day before the collections were made in order to assess the volume and concentration of nectar produced in the two populations. The following morning, from 8:00 am on, data on nectar volume and sucrose concentration were collected using $10 \mu \mathrm{L}$ microcapillary and graduated refractometer Eclipse $\left.{ }^{\circledR}\right)$, respectively. After the nectar was measured, the flowers in anthesis were removed, packed in Styrofoam box with ice gel, and taken to the laboratory so the grains could be counted and the viability analysis could be done.

A. nodosum flowers have two fillets with different heights (a larger and a smaller one). Therefore, an anther was selected from each fillet on the left side of the flower to prepare the slides according to the staining method using acetic carmine (Radford et al., 1974). The counting of viable and non-viable pollen grains was conducted in optical microscope, the reddish grains were considered viable and the non-stained ones were considered non-viable.

The differences in the volume and concentration of nectar, as well as the amount of viable and non-viable pollen from flowers from both areas were obtained through t-test, through $\log _{10}$ processing, whenever necessary. All the statistical analyses were conducted in Systat software 12.0 and in Graphpad Prism. 
Floral visitors

The monitoring of pollinators' behavior was done through visual observations in situ. Initially, the flower buds from the same 30 individuals selected in both areas were previously bagged. The observations were made in the same measurements - flower symmetry -, i.e., for 2 days in each area from 7:00 am to 03:00 pm, 10-minute sessions per hour, in each flower. The samples were accompanied since flower opening to flower fall. The branches were bagged in voile bags and observed throughout fruit development. After 64 days, the formed fruits were collected, dried in an oven at $60^{\circ} \mathrm{C}$ for 72 hours, weighed, and the number of seeds was counted.

Data describing the richness and frequency of bee visitations were recorded for further comparison between areas. Specimens were collected using netting and traps (baitodors) specific for each pollinator group. The traps consisted of perforated plastic bottles containing cotton and eucalyptol essence. They were hung at approximately $1.5 \mathrm{~m}$ from the soil and remained exposed for eight hours (Krug \& Alves-dosSantos, 2008). After this time, the traps were closed and the visitors were taken to the laboratory for identification.

We used the chi-square test of independence with Yates' correction to compare the total number of visitations to the flowers between the areas. We just considered the visitors that entered the flowers. We used Spearman's correlation to verify the association between FA (as length and width of flowers) and the number of bee visitations to the flowers. All the analyses were performed in the BioStat 5.0 software.

\section{Symmetry test in flowers}

Each individual $(\mathrm{N}=30$ individuals from each study area) had a bud at the bagged pre-anthesis to investigate the relationship between the change in floral symmetry and pollination. The bud was released the following day and it was kept full opened thereof. Observations were made during two days, in each area, from 7:00 am to 03:00pm, 10-minute session per hour in each flower. The samples were observed until the time of flower fall. After flower fall, every flower that was observed for floral visitors had their corollas collected to be measured through fluctuating asymmetry techniques (FA). The corolla was placed on a gridded surface and pressed with a glass to remain completely open. Length and width measurements on the right and left sides of the petals were taken using a digital caliper. The length of the petal was defined as the central length of the petal, from the lower part of the corolla. The width was defined as the greatest width presented by the petal perpendicularly to the length (Fig 1). Although the flowers were tubular, they had bilateral symmetry and the FA value was determined as the difference in length and width of the right hand side petals (Rw) and the left hand side petals (Lw), according to Møller and Eriksson (1994).

According to Potts and Strobeck (1986), it is necessary to firstly discriminate the FA of other types of asymmetry, such as the directional asymmetry and the anti-symmetry.
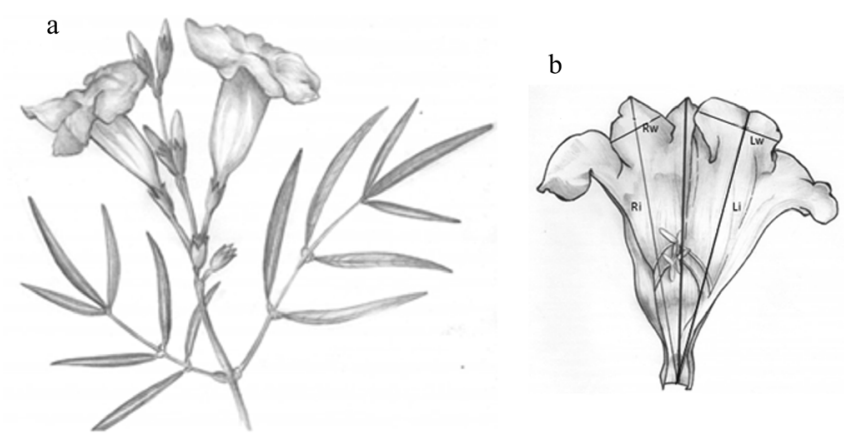

Fig 1. Shrub Adenocalymma nodosum, a) final portion of the bush illustrating the flowers and their flower buds; b) representative illustration of how a flower had the right (Rw) and left (Rw) width and the right $(\mathrm{Ri})$ and left $(\mathrm{Li})$ length measured in the petals. Measurements were always carried out in the central length and in the greatest width of the petal perpendicular to such length.

The FA indicates random and small symmetry deviations of a character and the frequency distribution of differences between the left and right sides (Rw-Lw); zero mean and normal distribution (bell-shaped curve). The directional asymmetry occurs whenever the development of a character in one side of the symmetry plane is greater than in the other side (Van Valen, 1962), most asymmetric individuals are in the same direction (Palmer, 2004) and have frequency distribution graph moved to the left or to the right. Since antisymmetry reflects lack of symmetry, but there is no specific displacement direction; thus, it results in a bimodal frequency plot (Sanseverino \& Nessimian, 2008).

The main ecological importance among asymmetry types is that FA is caused by environmental and biotic factors that can be measured and analyzed. Such measurements enable conclusions about how some variables affect the development of organisms. The fluctuating asymmetry in plants is often measured in sheets by considering the midrib as the axis of symmetry (Møller, 1995; Cornelissen \& Stiling, 2005; Alves-Silva \& Del-Claro, 2013). The FA of the sexual characters more strongly respond to environmental and genetic disorders in the analysis of specificity related to fluctuating asymmetry and to the character of sexual ornament developments such as flowers (Møller, 1995).

Initially, it was necessary to test the absence of directional asymmetry and anti-symmetry, which would represent the presence of fluctuating asymmetry (FA). Thus, the t-test and the Lilliefors normality test were performed to measure the directional asymmetry and antisymmetry, respectively, through the absolute difference between the right and left sides to the length and width. The differences between the left and right length and the width of the flower was not significantly deviated from zero in the post-mowing sample, respectively $(\mathrm{t}=0.03, \mathrm{df}=56, \mathrm{p}>0.05 \mathrm{t}=0.219, \mathrm{df}=$ $54 ; \mathrm{p}>0.05)$, as well as in the post-fire one $(\mathrm{t}=0.139, \mathrm{df}=58$, $p>0.05$ and $t=0.132, d f=58, p>0.05)$. All the data presented normality in the distribution ( $p>0.05$; Lilliefors test) and it validated the FA Hypothesis. 
We used the difference module between the left and the right side of the width and length (FA = average $|\mathrm{E}-\mathrm{D}|)$ to examine whether the different populations have different FA levels in their flowers. The comparison of the FA level means was performed through nonparametric Mann-Whitney.

\section{Soil analysis}

An abiotic measure was done to distinguish the stresses suffered by the two evaluated environments. Two soil samples were collected $50 \mathrm{~cm}$ from each sampled plant, one sample at $10 \mathrm{~cm}$ and another one at $20 \mathrm{~cm}$ depth, thus totaling 60 samples from each study area. The soil samples collected in the field were placed in plastic bags and sent to Laboratório de Análises de Solos e Calcários da Universidade Federal de Uberlândia in order to determine the following parameters: water $\mathrm{pH}(1: 2,5), \mathrm{K}\left(\mathrm{mg}_{\mathrm{dm}}{ }^{-3}\right), \mathrm{Ca}\left(\mathrm{cmol} \cdot \mathrm{dm}^{-3}\right), \mathrm{Mg}\left(\mathrm{cmol}^{-\mathrm{dm}^{-3}}\right)$, $\mathrm{Al}\left(\mathrm{cmol} . \mathrm{dm}^{-3}\right)$, Organic matter - M.O. (g.Kg $\left.{ }^{-1}\right), \mathrm{B}\left(\mathrm{mg}^{\mathrm{dm}} \mathrm{m}^{-3}\right)$, $\mathrm{Fe}\left(\mathrm{mg} \cdot \mathrm{dm}^{-3}\right), \mathrm{Mn}\left(\mathrm{mg}^{-\mathrm{dm}^{-3}}\right)$. The Mann-Whitney test was used to compare each parameter in the distinct areas except for $\mathrm{Fe}$ (Iron), which was measured through Students T-Test.

\section{Results}

The total length of the $A$. nodosum corolla in both areas was similar ( $\mathrm{t}=0.452 ; \mathrm{df}=54 ; \mathrm{p}=0.115)$, as well as the width of the right $(U=336.5 ; p=0.135)$ and left petals $(U=410.5$; $p=0.715$ ). Nevertheless, the flowers in the post-mowing area were significantly more asymmetrical than those of the postfire area $(U=174.0 ; d f=15 ; p<0.001$ for width of petals; $U$ $=193.0 ; \mathrm{df}=15 ; \mathrm{p}<0.001$ for length of petals) (Fig 2).

We recorded bee species as floral visitors in both studied areas: Bombus pauloensis Friese, 1913, Apis mellifera Linnaeus, 1758, Euglossa melanotricha Moure, 1967, Epicharis flava Friese, 1900, Trigona spinipes Fabricius, 1793 and some species were not collected from Ceratinini and Emphorini

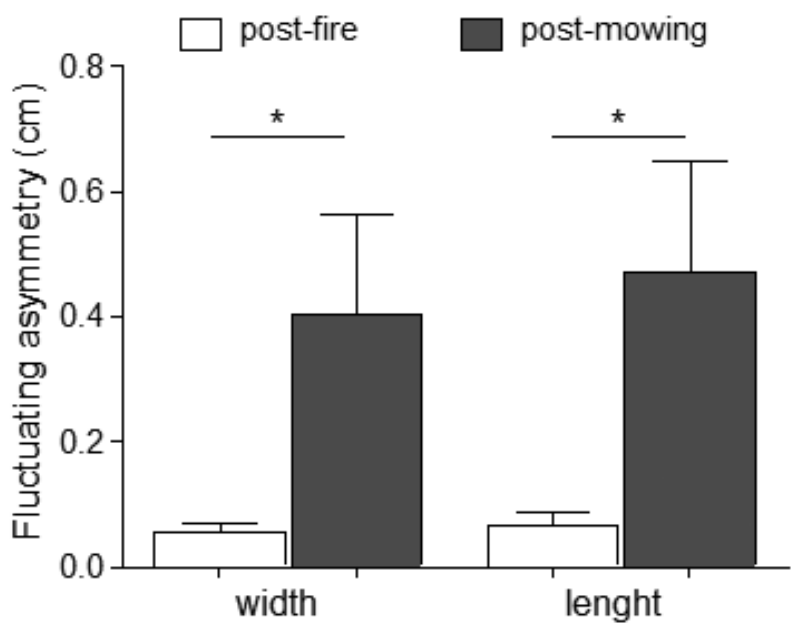

Fig 2. Fluctuating asymmetry $(\mathrm{cm})$ of the width and length of Adenocalymma nodosun petals on post-fire and post-mowing areas in February/March 2013 in Uberlândia, Brazil. The asterisks mean significant difference between areas (Mann-Whitney test). tribes. We recorded 204 bee visitations in flowers from the post-fire area, which corresponds to 0.75 visitations per hour, on average. We recorded 62 bee visitations in the flowers from the post-mowing area, which corresponds to 0.30 visitations per hour, on average. We detected variations in the total rate of visitations between areas $\left(\mathrm{X}^{2}=74.74\right.$; $\mathrm{df}=$ $1 ; \mathrm{p}<0.001)$. The number of visitations to flowers in the post-fire area was higher throughout the day than that of the post-mowing area (Fig 3). We recorded a similar visitation peak pattern and the subsequent visitation decline in the early afternoon, after 02:00 pm.

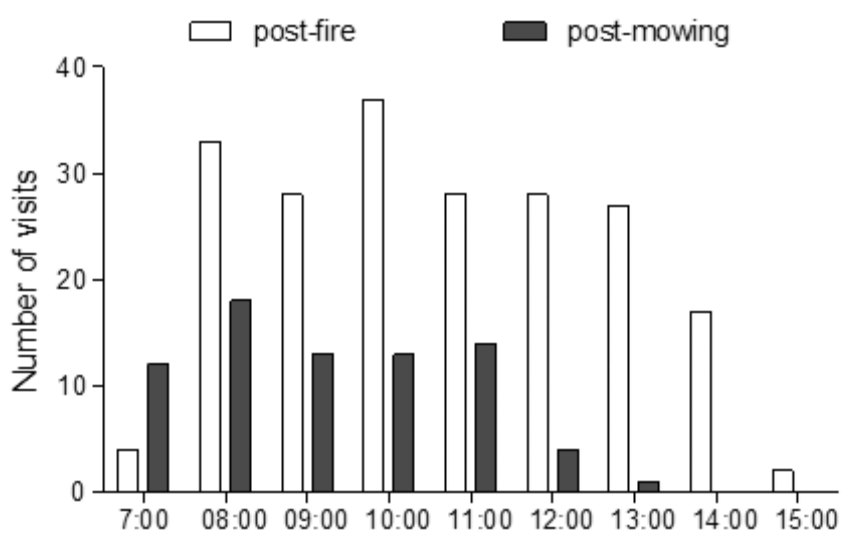

Fig 3. Number of bee visitations to Adenocalymma nodosum flowers in post-fire and post-mowing areas in Uberlândia, Brazil.

The volume of nectar was similar between the areas $(\mathrm{t}=1.76 ; \mathrm{df}=28 ; \mathrm{p}=0.08)$, as well as the total amount of produced $(\mathrm{U}=110.0 ; \mathrm{df}=28 ; \mathrm{p}=0.93)$ and unfeasible pollen $(t=1.185 ; d f=28 ; p=0.24)$. We just observed differences in the concentration of sugar in the nectar, and higher values of it in the post-fire area. $(\mathrm{t}=3.352 ; \mathrm{df}=27 ; \mathrm{p}<0.05)$.

The evaluated plants produced fruits in both areas. Although the burnt area has produced more fruits than the mowed area (33\% and $20 \%$, respectively), the difference was not significant. $\left(\chi^{2}=1.20 ; \mathrm{df}=1 ; \mathrm{p}=0.273\right)$. The fruit weight was also similar between areas $(t=0.721 ; d f=6 ; p=0.493)$, as well as the average number of seeds per fruit $(\mathrm{t}=1.07 ; \mathrm{df}=$ $6 ; p=0.07 ; 7.5$ seed per fruit in the burnt area and 4.43 seed per fruit in the mowed area).

There was no relation between the width of petals and of the number of bee visitations to flowers in both areas $\left(\mathrm{R}_{\mathrm{S}}\right.$ $=0.058 ; \mathrm{t}=0.305 ; \mathrm{p}=0.76$ in the mowed area; $\mathrm{R}_{\mathrm{S}}=0.008 ; \mathrm{t}=$ $0.004 ; p=0.996$ in the burnt area). We also found no relation between the length of the petals and the number of bee visitations to flowers in the burnt area $\left(\mathrm{R}_{\mathrm{S}}=0.294 ; \mathrm{t}=1.637\right.$; $\mathrm{p}=$ 0.136 ). However, there was significant positive relation between the length of the petals and the number of visitations to flowers in the mowed area $\left(R_{S}=0.401 ; t=2.275 ; p<0.05-\right.$ Fig. 4).

The assessed soil parameters were significantly different between areas (see Table 1), just $\mathrm{pH}$, at the depth $20 \mathrm{~cm}$, were similar in both areas. 
Table 1. Soil chemical features in the post-fire and post-mowing areas, in two different depths in Uberlândia, Brazil. We used the MannWhitney test in all the comparisons $(\mathrm{K}=$ potassium; $\mathrm{Ca}=$ Calcium; $\mathrm{Al}=$ aluminum; $\mathrm{O} . \mathrm{M}$.= organic matter, $\mathrm{P}=$ phosphorus $)$.

\begin{tabular}{|c|c|c|c|c|c|c|c|c|}
\hline \multirow[b]{2}{*}{ Parameters } & \multicolumn{2}{|c|}{$10 \mathrm{~cm}$} & \multirow[b]{2}{*}{$\begin{array}{l}\text { Test } \\
\text { value }\end{array}$} & \multirow[b]{2}{*}{$p$} & \multicolumn{2}{|c|}{$20 \mathrm{~cm}$} & \multirow[b]{2}{*}{$\begin{array}{l}\text { Test } \\
\text { value }\end{array}$} & \multirow[b]{2}{*}{$p$} \\
\hline & $\begin{array}{l}\text { Post-fire } \\
X \pm E P \\
(N=30)\end{array}$ & $\begin{array}{l}\text { Post-mowing } \\
\mathrm{X} \pm \mathrm{EP} \\
(\mathrm{N}=30)\end{array}$ & & & $\begin{array}{l}\text { Post-fire } \\
X \pm E P \\
(N=30)\end{array}$ & $\begin{array}{l}\text { Post-mowing } \\
X \pm E P \\
(\mathrm{~N}=30)\end{array}$ & & \\
\hline $\mathrm{Ph} \mathrm{H}_{2} \mathrm{O}(1: 2,5)$ & $5.95 \pm 0.06$ & $5.52 \pm 0.03$ & 119.5 & $<0.001$ & $6.9 \pm 0.64$ & $5.41 \pm 0.23$ & 341.5 & 0.108 \\
\hline $\mathrm{K}\left(\mathrm{mg} \cdot \mathrm{dm}^{-3}\right)$ & $0.26 \pm 0.01$ & $0.18 \pm 0.009$ & 63.00 & $<0.001$ & $0.15 \pm 0,024$ & $0.075 \pm 0.004$ & 109.5 & $<0.001$ \\
\hline $\mathrm{Al}\left(\mathrm{cmol} . \mathrm{dm}^{-3}\right)$ & $0.007 \pm 0.005$ & $0.33 \pm 0.035$ & 64.00 & $<0.001$ & $0.08 \pm 0.03$ & $0.5 \pm 0.02$ & 42.00 & $<0.001$ \\
\hline O. M. (g. $\left.\mathrm{Kg}^{-1}\right)$ & $5.39 \pm 0.021$ & $2.85 \pm 0.07$ & 30.00 & $<0.001$ & $4.08 \pm 0.14$ & $2.01 \pm 0.05$ & 0.000 & $<0.001$ \\
\hline $\mathrm{P}\left(\mathrm{mg} \cdot \mathrm{dm}^{-3}\right)$ & $0.4 \pm 0.08$ & $0.141 \pm 0.01$ & 28.00 & $<0.001$ & $0.23 \pm 0.14$ & $0.1 \pm 0.003$ & 19.00 & $<0.001$ \\
\hline
\end{tabular}

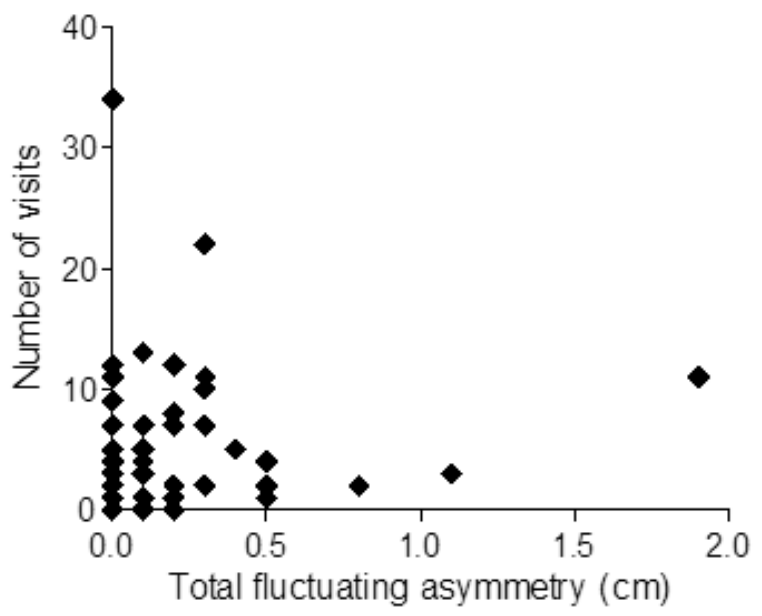

Fig 4. Relation (Spearman's correlation $-\mathrm{R}_{\mathrm{S}}=0.40 ; \mathrm{t}=2.27 ; \mathrm{p}<$ 0.05 ) between the number of bee visitations and the fluctuating asymmetry length $(\mathrm{cm})$ of the flowers in post-mowing area in Uberlândia, Brazil.

\section{Discussion}

Our results corroborate the initial hypothesis that $A$. nodosum flowers in the deforestation area are more asymmetric than those from the burned area. This result is an evidence that Cerrado plants may be less adapted to deforestation than to fire, since they have been facing fire events for thousand years in this biome. According to Ledru (2002), the oldest fossil record of fire actions in the Cerrado dates back to 32 thousand years ago. This period is prior to the arrival of humans to the Americas (Cooke, 1998). However, it is most likely that fire has occurred more often in the last 10,000 years due to indigenous practices such as hunting and gardening (Miranda et al., 2002, 2009). According to Simon et al. (2009), fire is a key driver of natural Cerrado plant selection in Brazil. It is evidenced by the sprouting ability of post-fire plants (Gottsberger \& Silberbauer-Gottsberger, 2008). This ability is a very common adaptive strategy of savanna species (Bond \& Midgley, 2001). However, the sprouting ability of post-fire plants may be limited by the annual burnings, which decrease the height and diameter of the sprouts and, consequently, increase the mortality rate (Medeiros \& Miranda, 2005). Annual burnings are common in Cerrado areas where fire is used to turn the natural environment into farmland and to renew pastures (Miranda et al., 2002).

On the other hand, deforestation in Brazil was boosted in the early 1970 s due to political incentive to productive occupations in Cerrado areas, mainly to agricultural production. This fact resulted in increased environmental degradation and in significant biodiversity losses (Myers et al., 2000; Oliveira \& Marquis, 2002). Currently, Cerrado fragments play a vital role in preserving the local endemic fauna and flora and they are considered an important biodiversity conservation area on the planet (hotspot sensu Myers et al., 2000). Thus, deforestation may be considered a recent event in the evolutionary history of Cerrado plants, whereas fire, and its impact on plant sprouting, may be higher due to the plants that are not yet adapted to this stress.

We suggest, that the sprouting of $A$. nodosum individuals after environmental stress (fire and deforestation) could have caused FA in flowers, and it corroborates the study by Alves-Silva and Del-Claro (2013), who found FA in post-fire Banisteriopsis campestris (Malpighiaceae) leaves. However, plants often have high degree of phenotypic plasticity associated with high FA levels (Schlichting, 1986) and stresses that generate faster plant growth may be more efficiently genetically corrected through the repairing or decreasing of FA (Møller \& Pomiankowski, 1993). It might have occurred in the plants from the post-fire area in the current study.

Fire and pruning can also indirectly act on the formation of plants in the affected areas through changes in soil chemistry. Our results show that the soil in the burnt area has concentrations of some nutrients in the upper layers higher than that of the soil in the deforested area. According to Kauffman et al. (1994), in the short term, fire becomes a mineralizing agent of organic matter through the increased availability of nutrients used for plant growth, especially at depths shorter than $0.5 \mathrm{~cm}$, due to ashes with high $\mathrm{P}, \mathrm{K}$ and $\mathrm{Ca}$ 
concentrations. The mineralization of organic matter causes faster plant growth in the burned area than in other areas because the nutrients provide quick benefit to pioneer plants, such as $A$. nodosum. Besides soil enrichment, there is decrease in the $\mathrm{Al}$ content shortly after the fire, and it can be understood as beneficial because this component can be toxic, especially if the soil $\mathrm{pH}$ is low (Coutinho, 1990). Ashes are usually rich in soluble oxide bases and carbonates, which become able to neutralize the $\mathrm{pH}$ of the soil (Oliveira \& Silva, 1994) by reducing the aluminum toxicity. This result was also showed in the current study because we found low aluminum rates in the soil of the post-fire area. Different processes occur in deforested areas, because the deposited plant matter is slowly decomposed, and it gradually provides nutrients to the plants, and hinders the rapid sprouting in most of the species (Zech et al., 1997). However, all these aspects will depend on the intensity, frequency, type of soil and climate and vegetation features before the fire, age and on the affected plant species (type of sprouting), as well as on the period of the year when the stress event occurred (see Catry et al., 2010).

We also detected a significantly higher concentration of sugar in the nectar of less asymmetric plants in burned area. Several studies have shown that FA may be featured as a quantitative and quality indicator of available resources of flowers pollinators (Wignall et al., 2006; Marazzi \& Endress, 2008; Wolowski \& Freitas, 2010; Potts, 2015). With more symmetrical flowers in the same species as a reliable sign of good quality resources to its visitors (Wignall et al. 2006). According to Cornelissen and Stiling (2005), FA may also directly influence plant metabolism and the production of chemical compounds such as floral nectar and Møller and Eriksson (1995) confirms the increased production of nectar and preference of pollinating insects for more symmetrical flowers. Other studies describe the recognition and preference of pollinators for better resource offers (Weiss, 1991; Gumbert, 2000; Chittka \& Thomson, 2004; Miller et al., 2011). In addition, our results support the idea of pollinators' preference for less asymmetrical flowers and a higher production of fruit (although not significant) in burned area than in the area of pruning. Sampaio et al. (2016) mentions that the species A. nodusum has naturally low reproductive success, which is usually related to the limitation of pollen or ovule. In this sense, the presence of asymmetry could further reduce productivity. Based on an evolutionary scale viewpoint, many plants were positively selected to increase the capacity of surviving the different types of fire regimes and resprouting systems in Cerrado (Simon et al., 2009). The same type of natural selection may not have been effective to plants under pruning stress. Therefore, in respect to plasticity and natural selection, it is possible that $A$. nodosum individuals from the burned area in the current study may be undergoing a selection process more advanced than that of individuals from the deforested area. Innovative studies, which assess the effects of environmental stresses on the development and fitness of plants, provide an important advance to the understanding of insect-plant interactions and of their co-evolutionary aspects, especially in Cerrado areas where burning and deforestation are frequently performed by humans. The FA was widely used in these studies as a way to provide relevant information to biology conservation.

\section{Acknowledgements}

The authors thank the staff of Clube de Caça e Pesca Itororó de Uberlândia, where the study was carried out. We are grateful to Solange Cristina Augusto for their invaluable help in species identification. This work was financial supported by the National Post-Doctoral Plan (Coordenação de Aperfeiçoamento de Pessoal de Nível Superior - Plano Nacional de Pós-Doutorado; CAPES-PNPD/ 1533482 - Pós-Graduação em Ecologia e Conservação - UFU) for VS; thanks to CNPq (PQ 301605/2013-0); CNPq (473055/2012-0) for KDC and FAPEMIG for awarding fellowships to AAV.

\section{References}

Alves-Silva, E. \& Del-Claro, K. (2013). Effect of postfire resprouting on leaf fluctuating asymmetry, extrafloral nectar quality, and ant-plant-herbivore interactions. Naturwissenschaften, 100: 525-532. doi: 10.1007/s00114-013-1048-z.

Alves-Silva, E. \& Del-Claro, K. (2015). Herbivory-induced stress: Leaf developmental instability is cause by herbivore damage in early stages of leaf development. Ecological Indicators, 61: 359-365. doi:10.1016/j.ecolind.2015.0.036.

Bond, W.J. \& Midgley, J.J. (2001). Ecology of sprouting in woody plants: the persistence niche. Trends in Ecology and Evolution, 16: 45-51. doi: 10.1016/S0169-5347(00)02033-4.

Bond, W.J. \& Keeley, J.E. (2005). Fire as a global 'herbivore': the ecology and evolution of flammable ecosystems. Trends in Ecology and Evolution, 20: 387-394. doi: 10.1016/j.tree. 2005.04.025

Catry, F., Silva, J.S. \& Fernandes, P. (2010). Efeitos do fogo na vegetação. In F. Moreira, F.X. Catry, J.S. Silva \& R. Francisco (Eds.), Ecologia do fogo e gestão de áreas ardidas (pp. 49-86). Lisboa, ISA Press.

Chittka, L. \& Thomson, J.D. (2004). Cognitive ecology of pollination: animal behavior and floral evolution. Cambridge University Press, Cambridge.

Christian, D.G., Riche, A.B. \& Yates, N.E. (2008). Growth, yield and mineral content of Miscanthus x giganteus grown as a biofuel for 14 successive harvests. Industrial Crops and Products, 28: 320-327.

Cooke, R. (1998). Human settlement of Central America and Northernmost South America (14,000-8000 BP). Quaternary International, 49/50: 177-190. 
Cornelissen, T. \& Stiling, P. (2005). Perfect is best: low leaf fluctuating asymmetry reduces herbivory by leaf miners. Oecologia, 142: 46-56. doi: 10.1007/s00442-004-1724-y.

Coutinho, L.M. (1990). Fire in the Ecology of the Brazilian Cerrado. In J.G. Goldammer (Ed.), Fire in the Tropical Biota Ecological Studies (pp. 82-105). Spring-Verlag, Berlin Heidelberg.

Cuevas-Reyes, P., Fernandes, G.W., González-Rodríguez, A. \& Pimenta, M. (2011). Effects of generalist and specialist parasitic plants (Loranthaceae) on the fluctuating asymmetry patterns of ruprestrian host plants. Basic and Applied Ecology, 12: 449-455. doi: 10.1016/j.baae.2011.04.004

Daloso, D.M. (2014). The ecological context of bilateral symmetry of organ and organisms. Natural Science, 6: 184190. doi:10.4236/ns.2014.64022

Del-Claro, K. \& Marquis, R.J. (2015). Ant species identity has a greater effect than fire on the outcome of an ant protection system in Brazilian Cerrado. Biotropica, 47: 459-467. doi: 10.1111/btp. 12227

Díaz, M., Pulido, F.J. \& Moller, A.P. (2004). Herbivore effects on developmental instability and fecundity of holm oaks. Oecologia, 139: 224-234. doi: 10.1007/s00442-004-1491-9.

Eiten, G. (1972). The cerrado vegetation of Brazil. Botanical Review, 38: 201-341.

Faegri, K. \& Van Der Pijl, L. (1976). The principles of pollination ecology. $3^{\circ} \mathrm{ed}$. Oxford: Pergamon Press, $256 \mathrm{p}$.

Fagundes, R., Anjos, D.V., Carvalho, R. \& Del-Claro, K. (2015). Availability of food and nesting-sites as regulatory mechanisms for the recovery of ant diversity after fire disturbance. Sociobiology, 62: 1-9. doi: 10.13102/socio biology.v62i1.1-9

Fernandes, P. \& Rigolot, E. (2007). The fire ecology and management of maritime pine (Pinus pinaster Ait.). Forest Ecology and Management, 241: 1-13. doi: 10.1016/j.foreco. 2007.01.010.

Ferreira, C.A. \& Torezan-Silingardi, H.M. (2013). Implications of the floral herbivory on Malpighiacea plant fitness: visual aspect of the flower affects the attractiveness to pollinators. Sociobiology, 60: 323-328. doi: 10.13102/socio biology.v60i3.323-328.

Frey, F.M. \& Bukoski, M. (2013). Floral symmetry is associated with flower size and pollen production but not insect visitation rates in Geranium robertianum (Geraniaceae). Plant Species Biology, 29: 272-280. doi: 10.1111/1442-1984.12021

Gottsberger, G. \& Silberbauer-Gottsberger, I. (2008). Life in the cerrado: a South American tropical seasonal. Flora, 203: 103-104. doi: 10.1016/j.flora.2007.06.001

Graham, J.H., Raz, S., Hel-Or, H. \& Nevo, E. (2010). Fluctuating asymmetry: methods, theory, and applications.
Symmetry, 2: 466-540. doi: 10.3390/sym2020466.

Gumbert, A. (2000). Color choices by bumble bees (Bombus terrestris): Innate preferences and generalization after learning. Behavioral Ecology and Sociobiology, 48: 36-43.

Hajabbasi, M.A., Jalalian, A. \& Karimzadeh, H.R. (1997). Deforestation effects on soil physical and chemical properties, Lordegan, Iran. Plant and Soil, 2: 301-308.

Hoffmann, W.A. (1998). Post-burn reproduction of woody plants in a neotropical savanna: The relative importance of sexual and vegetative reproduction. Journal of Applied Ecology, 35: 422-433.

Hoffman, W.A. \& Moreira, A. (2002). The role of fire in population dynamics of woody plants. In O.S. Oliveira \& R.J. Marquis (Eds.), The cerrados of Brasil: ecology and natural history of a neotropical savanna (pp. 159-177). New York: Columbia University Press.

Kauffman, D., Cummings, D. \& Ward, D. (1994). Relationships of fire, biomass and nutrient dynamics along vegetation gradient in the Brazilian Cerrado. Journal of Ecology, 82: 519-531.

Krug, C. \& Alves-dos-Santos, I. (2008). O uso de diferentes métodos para amostragem da fauna de abelhas (Hymenoptera, Apoidea), um estudo em floresta ombrófila mista em Santa Catarina. Neotropical Entomology, 37: 265-278. doi: 10.15 90/ S1519-566X2008000300005

Ledru, M.P. (2002). Late Quaternary history and evolution of the cerrados as revealed by palynological records. In P.S. Oliveira \& R.J. Marquis (Eds.), The Cerrados of Brazil: Ecology and Natural History of a Neotropical Savanna (pp. 33-50). New York: Columbia University Press.

Marazzi, B. \& Endress, P. (2008). Patterns and development of floral asymmetry in Senna (Leguminosae, Cassinae). The American Journal of Botany, 95: 22-40. doi: 10.3732/ajb.95.1.22.

Medeiros, M.B. \& Miranda, H.S. (2005). Mortalidade pósfogo em espécies lenhosas de campo-sujo submetido a três queimadas prescritas anuais. Acta Botanica Brasilica, 19: 493-500.

Miller, R., Owens \& S.J., Rorslett, B. (2011). Plants and colours: Flowers and pollination. Optics and Laser Technology, 43: 282-294. doi: 10.1016/j.optlastec.2008.12.018.

Milligan, J.R., Krebs, R.A. \& Mal, T.K. (2008). Separating developmental and environmental effect on fluctuating asymmetry in Lythrum salicaria and Penthorum sedoides. Journal of Plant Sciences, 169: 625-630. doi: 10.1086/533600

Miranda, H.S., Bustamante, M.C. \& Miranda, A. (2002). The fire fator. In PS, Oliveira \& RJ Marquis (Eds.), The Cerrados of Brazil: Ecology and Natural History of a Neotropical Savanna (pp. 51-68). New York: Columbia University Press.

Miranda, H.S., Sato, M.N., Nascimento-Neto, R. \& Aires, F.S. (2009). Fires in the Cerrado, the Brazilian savanna. In 
M.A. Cochrane (Ed.), Tropical fire ecology: climate change, land use, and ecosystem dynamics (pp. 427-450). Chichester: Springer-Praxis.

Møller, A.P. (1995). Bumblebee preference for symmetrical flowers. Proceedings of the National Academy of Science of the USA, PNAS, 92: 2288-2292.

Møller, A.P. \& Eriksson, M. (1994). Patterns of fluctuating asymmetry in flowers: implications for sexual selection in plants. Journal of Evolutionary Biology, 7: 97-113.

Møller, A.P. \& Eriksson, M. (1995). Pollinator preference for symmetrical flowers and sexual selection in plants. Oikos, 73: 15-22.

Møller, A.P. \& Pomiankowski, A. (1993). Fluctuating asymmetry and sexual selection. Genetica, 89: 267-279.

Møller, A.P. \& Swaddle, J.P. (1997). Asymmetry, developmental stability, and evolution. University Press, Oxford, $302 \mathrm{p}$

Myers, N., Mittermeier, R.A., Mittermeier, C.G., Da Fonseca, G.A.B. \& Kent, J. (2000). Biodiversity hotspots for conservation priorities. Nature, 403: 853-858.

Oliveira, M.E. \& Silva, I.L. (1994). Efeitos do fogo sobre o solo. Floresta e Ambiente, 1: 142-145.

Oliveira, O.S. \& Marquis, R.J. (2002). The Cerrados of Brazil: Ecology and natural history of a Neotropical Savanna. New York, Columbia University Press, 398 p.

Pellegrino, G. (2015). Pollinator limitation on reproductive success in Iris tuberosa. AoB Plants, 7: plu089. doi: 10.1093/ aobpla/plu089

Palmer, A.R. (2004). Symmetry breaking and the evolution of development. Science, 306: 828-833. doi: 10.1126/science. 1103707.

Palmer, A.R. \& Strobeck, C. (1986). Fluctuating asymmetry: measurement, analysis, patterns. The Annual Review of Ecology, Evolution and Systematics, 17: 391-421.

Polak, M. (2003). Developmental instability - causes and consequences. University Press, Oxford, 459 p.

Potts, J.G. (2015). Effects of Floral Symmetry on Pollination in Bidens aristosa. The Southwestern Naturalist, 60: 370-373. doi: 10.1894/0038-4909-60.4.370

Radford, A.E., Dickinson, W.C., Massey, J.R. \& Bell, C.R., 1974. Vascular plant systematics. New York: Harper \& Row Publishers, $891 \mathrm{p}$.

Réu, W.F. \& Del-Claro, K. (2005). Natural History and Biology of Chlamisus minax Lacordaire (Chrysomelidae: Chlamisinae). Neotropical Entomology, 34: 357-362.

Rizzini, C.T. \& Heringer, E.P. (1962). Studies on the underground organs of the trees and shrubs from some southern Brazilian savannas. Anais da Academia Brasileira de Ciências. 34: 235-247.

Sampaio, D.S., Mendes-Rodrigues, C., Engel, T.B.J., Rezende, T.M., Bittencourt-Junior, N.S. \& Oliveira, P.E. (2016). Pollination biology and breeding system of syntopic Adenocalymma nodosum and A. peregrinum (Bignonieae, Bignoniaceae) in the Brazilian savanna. Flora, 223: 19-29. doi:10.1016/j.flora.2016.04.009

Sanseverino, A.M. \& Nessimian, J.L. (2008). Larvas de Chironomidae (Diptera) em depósito de folhiço em um riacho de primeira ordem da Mata Atlântica (Rio de Janeiro, Brasil). Revista Brasileira de Entomologia, 52: 95-104. doi: 10.1590/ S0085-56262008000100017

Schlichting, C.D. (1986). The evolution of phenotypic plasticity in plants. The Annual Review of Ecology, Evolution and Systematics, 17: 667-693.

Schmidt, I.B., Sampaio, A.B. \& Borghetti, F., 2005. Efeitos da época de queima sobre a reprodução sexuada e estrutura populacional de Heteropterys pteropetala (Adr. Juss.), Malpighiaceae, em áreas de Cerrado sensu stricto submetidas a queimas bienais. Acta Botanica Brasilica, 19: 927-934.

Silva, I.A. \& Batalha M.A. (2010a). Woody plant species co-occurrence in Brazilian savannas under different fire frequencies. Acta Oecologica, 36: 85-91. doi: 10.1016/j. actao.2009.10.004.

Silva, I.A. \& Batalha, M.A. (2010b). Phylogenetic structure of Brazilian savannas under different fire regimes. Journal of Vegetation Science, 21: 1003-1013. doi: 10.1111/j.16541103.2010.01208.x

Simon, M.F., Grether, R., Queiroz, L.P., Skema, C., Pennington, R.T. \& Hughes, C.E. (2009). Recent assembly of the Cerrado, a Neotropical plant diversity hotspot, by in situ evolution of adaptations to fire. Proceedings of the National Academy of Sciences, PNAS, 106: 20359-20364. doi: $10.1073 /$ pnas.0903410106

Smithwick, E.A.H., Turner, M.G., Mack, M.C. \& Chapin III, F.S.C., 2005. Post fire soil N cycling in northern conifer forests affected by severe, stand-replacing wildfires. Ecosystems, 8: 163-181. doi: 10.1007/s10021-004-0097-8

Torezan-Silingardi, H.M., 2011. Predatory behavior of Pachodynerus brevithorax (Hym.: Vespidae, Eumeninae) on Endophytic herbivore beetles in the Brazilian Tropical Savanna. Sociobiology, 57: 181-189.

Tresvenzol, L.M.F., Fiuza, T.S., Rezende, M.H., Ferreira, H.D., Bara, M.T.F., Zatta, D.T. \& Paula, J.R. (2010). Morfoanatomia de Memora nodosa (Silva Manso) Miers, Bignoniaceae. Revista Brasileira de Farmacognosia, 20: 833-842. doi: 10.1 590/S0102-695X2011005000002

Van Valen, L. (1962). A study of fluctuating asymmetry. Evolution, 16: 125-142. 
Weiss, M.R. (1991). Floral color changes as cues for pollinators. Nature, 354: 227-229.

Wignall, A.E., Heiling, A.M., Cheng, K. \& Herberstein, M.E. (2006). Flower symmetry preferences in honeybees and their crab spider predators. Ethology, 112: 510-518. doi: 10.1111/j.1439-0310.2006.01199.x

Wolowski, M. \& Freitas, L. (2010). Sistema reprodutivo e polinização de Senna multijuga (Fabaceae) em Mata Atlântica Montana. Rodriguésia, 61: 167-79.
Zech, W., Senesi, N., Guggenberger, G., Kaiser, K., Lehmann, J., Miano, T.M., Miltner, A. \& Shroth, G. (1997). Factors controlling humification and mineralization of soil organic matter in the tropics. Geoderma, 79: 117-161.

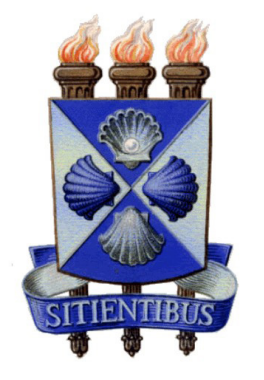

